Srđan Šapić, Jovana Lazarević, Veljko Marinković University of Kragujevac, Faculty of Economics, Serbia

\title{
Consumer Lifestyle Forming Under the Influence of National Culture
}

DOI: 10.7595/management.fon.2021.0028

Abstract:

Research Question: This paper examines the influence of femininity and collectivism as a dimension of Serbian national culture on activities, interests and opinions, i.e. consumer lifestyle components. Motivation: Consumer lifestyle is largely shaped by the effects of the culture to which consumers belong. Starting from the relevant Kotler and Keller (2017) consumer behaviour model that demonstrates the previously given fact, as well as identified research gap related to investigating the influence of Hofstede's national culture dimensions on activities, interests and opinions as lifestyle components, the study gives useful insights into the importance of knowing and respecting cultural differences when defining marketing strategies that aim to shape or influence a particular consumer lifestyle. The study contributes to the existing literature by providing a new idea for developing a research framework that could be used in cross-cultural or consumer behaviour studies. Idea: The basic idea of this study is to empirically test the relationship between national culture dimensions and consumer lifestyle components. The study was conducted using collectivism and femininity as independent variables, and activities, interest and opinions, i.e. lifestyle components as dependent variables. Data: Empirical research was conducted on a sample of 251 consumers from central Serbia using a survey method during July and August 2020. Tools: Processing of primary data was performed using statistical software SPSS 20 and AMOS 20 utilizing descriptive statistics, reliability analysis, correlation analysis, confirmatory factor analysis and structural equation modelling. Findings: The study first confirms the presence of collectivism and femininity as Serbian national culture dimensions, and then indicates the existence of a statistically significant effect of observed national culture dimensions on consumer lifestyle components. Related to this, results indicate the existence of a statistically significant effect of femininity on activities and opinions, while collectivism determines only activities as a lifestyle component. Contribution: The paper provides an analysis of national culture influence on lifestyle as an important sociological determinant of consumer behaviour and also provides practical implications for marketers.

Keywords: lifestyle, national culture, dimensions of national culture, collectivism, femininity, AIO tehnique

JEL Classification: M31, Z10

\section{Introduction}

Culture refers to the broadest framework of human behaviour, influences socialization of individuals, defines a framework for formation of consumer goals and ways of achieving them. A generally accepted definition of culture was given by Geert Hofstede $(1994$, p. 1) who defines culture as "the collective programming of the mind which distinguishes the members of one category of people from another". Authors Zolt \& Kokovic (2017, p. 23) state that culture represents "the sum of material, intelectual and artistical creations of people, their ways of behaviour and actions which realize social relations and social activities, as well as any creative expresison that does not have to be achieved". On the other hand, Wild \& Wild (2016, p. 70) see culture as "the set of values, beliefs, rules, and institutions held by a specific group of people". Starting from the influence of culture on behaviour of individuals, culture can be defined as "a set of learned beliefs, values and customs that create norms of behaviour in a particular society" (Yau, 1994. p. 49). For the purpose of understanding the influence of culture on consumer behaviour, culture is defined as "a list of acceptable values, beliefs, customs, rituals and myths that are characteristic of members of a particular society (Maricic, 2011, p. 208). Kovac-Znidersic \& Maric (2007) state that values, beliefs, customs and rituals influence people's behaviour and lifestyle. Cleveland, Rojas-Mendez, Laroche \& Papadopoulos (2016) point out that culture is an important determinant of consumer behaviour and disparities of the same across countries. 
Culture is a social characteristic of people that determines the way people live, how they dress, where they travel, how they eat, etc. Culture determines interpersonal relationships, social roles, gender roles, learning, work, rest. In fact, the effects of culture permeate every segment of an individual's life. On the other hand, lifestyle can be briefly explained as the umbrella concept related to behaviour including relations with others, consumption, leisure, work, religious activity etc. (Zhang, Lu \& Sun, 2021). Vijloen, van der Spuy \& du Rand (2018) indicate that lifestyle can be viewed as a habit stemming from rules and standards that influence consumer behaviour. In this regard, it is possible to see a clear relationship between culture and consumer lifestyle. Accordingly, Brocic (1995) states that culture is one of the important factors that determine individual's lifestyle. Sethna \& Blythe (2016) indicate that culture is one of main triggers of all consumer activities. Examining lifestyle differences of consumers living in different cultural backgrounds has been the subject of analysis by numerous empirical studies (Reid, Li, Bruwer \& Grunert, 2001; Lee \& Sparks, 2007; Donnelly et al., 2011; Mangruwa, Zaki, Mahdzir \& Khalid, 2015), but a small number of studies have focused specifically on the influence of the national culture dimensions on lifestyle (Sun, Horn \& Merritt, 2004; Tao, 2006; Nagy \& Konyha, 2018). Finally, according to authors' knowledge, the literature misses research related to the national culture dimensions influence on activities, interests and opinions as lifestyle components, where a research gap was identified.

The subject of the paper refers to the analysis of national culture, observed through dimensions, as determinant of consumer lifestyle. Empirical analysis is based on examining the influence of masculinity/femininity and individualism/collectivism, as dimensions of national culture defined by Geert Hofstede (1980), on consumer lifestyle measured using AlO techniques (Wells \& Tigert, 1971). Precisely, the paper will look at the influence of femininity and collectivism given the fact that these dimensions, according to the Hofstede's index, are dominant in Serbian national culture, as indicated by the value of masculinity index 43 and the value of individualism index 25 on the scale from 0 to 100 (Sapic \& Golo, 2017; Hofstede Insights, 2020). The first part of the paper analyzes dimensions of national culture defined by Hofstede (1980). The second part deals with the concept of consumer lifestyle and the most important psychographic techniques for measuring it. The third part presents theoretical models and results of previously conducted studies on the relationship between national culture and consumer lifestyle. In the fourth part the methodology of the study is defined and then results of the empirical study are shown. The concluding part highlights the most important knowledge, limitations of the study and possible directions for future research.

\section{National Culture Dimensions}

The best-known cultural framework is defined by Hofstede (1980) and includes uncertainty avoidance, power distance, individualism/collectivism and masculinity/femininity as dimensions of national culture. Uncertainty avoidance indicates how strongly people feel the need to operate under well-organized and predictable circumstances or how much they are able to cope with unplanned situations (Beugelsdijk \& Welzel, 2018). In societies with a low degree of uncertainty avoidance, individuals have tolerance for ambiguity and innovativeness and feel satisfaction with life, while individuals in high uncertainty avoidance societies tend to avoid uncertainty and ambiguity, feel stress and anxiety (de Mooij, 2017). Individualism/collectivism refers to "the degree to which individuals in a society are integrated into groups" (Sapic \& Filipovic, 2019, p. 123). In individualistic cultures relationships between individuals are weak and everyone cares about themselves and their own interests. In collectivistic cultures there are strong relations between group members, harmony and mutual care. Power distance indicates the degree to which society accepts and expects power to be unequally distributed in society (de Mooij, 2017). In societies with a high power distance there is clear hierarchy and dominance of individuals with power. In societies with a low power distance everyone has equal rights and inequalities are reduced to a minimum. Masculinity/femininity focuses on "wheater gender roles are distinct (masculine cultures) or blurred (feminine cultures) within a society" (Mansson \& Sigurdardottir, 2017, p. 161). Dominance of masculinity implies success, desire to acquire wealth and achievements, while dominance of femininity refers to the need for social contacts and general well-being (Sapic, 2015).

\section{Consumer Lifestyle}

Lifestyle can most easily be understood as the way a person lives or wants to live. According to Chouk \& Mani (2019, p. 452), lifestyle refers to "individual factors that allow differentiation in the manner of being and living". An individual can express himself, his needs and activities through different lifestyles, i.e. through the way he eats and what he eats, how and where he travels, how and where he lives, what he dresses, how well he is educated, how much he is politically or religiously engaged, how he spends free time, how he communicates with others (Jensen, 2007). Lifestyle is formed as a consequence of interaction of internal and external factors (Kotler \& Keller, 2017) and has strong effect on consumer behaviour when buying products and services. The operative technique for measuring consumer lifestyle is psychography by offering 
consumers certain statements regarding their attitudes, values, beliefs, interests, activities, and opinions. Consumers express their degree of agreement or disagreement with statements. The essence of psychographic analysis is to relate the observed psychographic variables to behaviour of individuals when purchasing and using products and services. The best-known technique for measuring consumer lifestyle is the AIO technique by Wells \& Tigert (1971). AIO measures activities, i.e. how people spend their time and money, what their interests are or what they consider important as well as their opinions about themselves and world around them (Bruwer, Roediger \& Herbst, 2017). AIO tecnique also includes consumer characteristics such as age, education, income, phase in the life cycle, etc. Psychographic analysis based on the AIO technique requires two steps (Solomon, Bamossy, Askegaard \& Hogg, 2016). The first step is to determine which lifestyle segments are characteristic of heavy, moderate or light users of a particular product, and also to investigate patterns of usage and attitudes toward the product. After targeting primarly heavy users, in the next step of the analysis marketers consider how these consumers relate to the brand, i.e. their reasons for buying and using a paricular brand.

\section{National Culture Role in Lifestyle Forming}

The first link between culture and consumer lifestyle was presented in the work of Lazer (1963) (according to Lawson \& Todd, 2002) who proposed lifestyle hierarchy according to which group and individual expectations and values originate from the culture in which an individual lives. Expectations and values translate into lifestyle patterns that further determine purchasing decisions and consumer reactions. In addition to this hierarchy, there are certain models of consumer behaviour that indicate a clear link between culture and lifestyle such as the model given by Kotler \& Keller (2017). This model views culture and lifestyle as determinants of consumer behaviour, where lifestyle is formed under the influence of culture in which an individual lives. Culture as an external determinant combined with internal determinants such as learning, perception, emotions, motives and attitudes defines consumer lifestyle, which is then translated into consumer desires and needs and reflected in purchasing decisions.

The literature contains results of empirical research focused on the study of lifestyles in areas such as tourism, nutrition, recreation or health in different cultural environments. The role of culture in shaping a healthy lifestyle is of great importance. Katz (2014) points out that a healthy lifestyle does not develop in hospitals but in places where people live, work, pray, learn and love, namely, that the decision to lead a healthy lifestyle is the result of cultural influence. Donnelly et al. (2011) empirically confirm that the effect of culture is crucial when it comes to decision of women in Qatar to lead a healthy lifestyle. Another area in which national culture has a significant impact on consumer lifestyle is tourism. It has been empirically proven that cultural differences determine preferences and travel patterns as in the study of Lee \& Sparks (2007) or Iversen, Hem \& Mehmetoglu (2016). The effects of culture on lifestyle in terms of nutrition were examined in a study by Reid et al. (2001) who have proved that consumers living in different national cultures have different preferences regarding the manner and motive of buying food, the way of preparation, the way of consuming food, etc. Cultural influence on lifestyle related to energy use and environmental protection has also been confirmed in empirical studies (Mangruwa et al., 2015; Nguyen, Lobo \& Greenland, 2017).

When it comes to the role of masculinity/femininity and individualism/collectivism in shaping consumer lifestyles, Tao (2006) has examined similarities and differences in terms of activities, interests and opinions between American and Taiwanese consumers, taking into account differences concerning cultural dimensions in which these consumers live. A study that indicates the existence of insignificant relationship between masculinity/femininity and consumer lifestyle and a significant but weak influence of individualism on lifestyle is a study by Nagy \& Konyha (2018) where the subject of analysis relates to the influence of national culture dimensions on environment protection as an essential aspect of sustainable lifestyle. Tan, Shaw, Cheng \& Kim (2013) examine the emphasis on male values in the most popular American, Taiwanese and Chinese lifestyle magazines for men. The results obtained by authors indicate the absence of differences in terms of male value types that are emphasized in lifestyle magazines in observed countries with different cultural environments. A study examining differences in consumer lifestyle from individualistic and collectivist cultures was conducted by Sun et al. (2004) where it was proven that consumers from individualistic cultures were more optimistic, more satisfied with life and financial situation and preferred to travel, in relation to consumers who came from collectivist cultures. Previously presented theoretical and empirical knowledge is a basis for testing the following research hypotheses:

H1: Collectivism has a statistically significant effect on consumer lifestyle in Serbia. H1a: Collectivism has a statistically significant effect on consumer activities.

$\mathrm{H} 1 \mathrm{~b}$ : Collectivism has a statistically significant effect on consumer interests.

H1c: Collectivism has a statistically significant effect on consumer opinions. 
H2: Femininity has a statistically significant effects on consumer lifestyle in Serbia. $\mathrm{H} 2 \mathrm{a}$ : Femininity has a statistically significant effects on consumer activities. $\mathrm{H} 2 \mathrm{~b}$ : Femininity has a statistically significant effects on consumer interests. H2c: Femininity has a statistically significant effects on consumer opinions.

\section{Research Methodology}

The conducted empirical analysis is based on primary data collected by surveying 251 consumers from the territory of central Serbia. The questionnaire (available at: https://pdfhost.io/v/j9KREgVJ4_Appendixpdf.pdf?fbclid=IwAR0iHUSTAcjAPeyxe7XGZxAQRt48al1iVx4n9IW SOWFkTeJdvkyOLnve2yc), which was distributed to consumers in person during July \& August 2020, includes three parts. The first part of the questionnaire consists of 8 statements (taken from: Yoo, Donthu \& Lenartowicz, 2011; Guseva, 2013; Kabir \& Sarker, 2015; Langat \& Oduor, 2015; Mojic, Jovancevic \& Jovancevic, 2018) that refer to femininity and collectivism as national culture dimensions. The second part of the questionnaire includes 9 statements (taken from: Wells \& Tigert, 1971; Rathod \& Sony, 2014; AlDmour, Hammadan, Al-Dmour, Alrowwad \& Khwaldeh, 2017) that refer to observed components of consumer lifestyle. The third part of the questionnaire contains demographic questions such as gender, age and level of education. Despite the fact that the paper observes national culture dimensions given by Hofstede, which are almost always used in analysis of culture (Albors-Garrigos, Frass, Schoeneberg \& Signes, 2017), it is important to emphasize that measuring of dimensions in the paper is done at one national culture level in line with methodology of authors such as Sharma (2010), Yoo et al. (2011) \& others. Accordingly, statements in the first two parts of the questionnaire are measured by a seven-point Likert scale where grade 1 implies absolute disagreement and grade 7 absolute agreement with a given statement. When observing the structure of the surveyed sample, it is dominated by female respondents (137 or $54.6 \%$ ), while there are fewer male respondents (114, i.e. $45.4 \%)$. According to age, the largest percentage of respondents $(47.8 \%$, i.e. 120) is between 26 and 45 years old, followed by 62 respondents (24.7\%) aged between 18 and 25, followed by 49 respondents (19.5\%) who are between 46 and 55 years old, while the least number of respondents are 56 years old and older (20 or $8 \%)$. In terms of employment status, most respondents are employed (113 or $45 \%), 65$ are unemployed, which makes $25.9 \%$ of the sample, 51 respondents $(20.3 \%)$ are students, while the fewest are pensioners (22 or $8.8 \%$ ). Statistical software SPSS 20 and AMOS 20 were used to process the primary data. Descriptive statistics for determining the sample structure and values of arithmetic means for national culture dimensions, reliability analysis of observed variables and correlation analysis for determining degree of linear dependence between variables were conducted in SPSS software. Hypotheses testing was performed in AMOS 20 software, where the validity of research models was tested by confirmatory factor analysis. Then structural equation modeling was applied in order to test the observed effects of independent on dependent variables. The validity of the model was measured by calculating GFI (goodness-of-fit index), CFI (comparative fit index), TLI (Tucker-Lewis index), IFI (incremental fit index) and RMSEA (root mean square error of approximation) index and $x 2 / d f$ ration. The AIO psychographic technique (Wells \& Tigert, 1971) was used to measure lifestyle, as is often used in cultural research (Tao, 2006; Lee \& Sparks, 2007; Kucukusta \& Denizci Guillet, 2016).

\section{Research Results and Discussion}

In the first step of statistical analysis, reliability of variables was tested by measuring internal consistency of statements that make them up. Reliability is reflected by value of the Cronbach's alpha coefficient and 0.6 is taken as a minimal threshold value (Cossio-Silva, Revilla-Camacho, Vega-Vazquez \& Palacios-Florencio, 2016). Obtained values (Table 1) indicate that all variables have a satisfactory reliability level.

Table 1: Cronbach's alpha coefficient values

\begin{tabular}{|c|c|}
\hline Variable & Cronbach's alpha \\
\hline Collectivism & $\mathbf{0 . 7 8 8}$ \\
\hline Femininity & 0.605 \\
\hline Activities & 0.718 \\
\hline Interests & 0.727 \\
\hline Opinions & 0.776 \\
\hline
\end{tabular}

Source: authors 
Testing the influence of independent variables on dependent ones was preceded by examining the presence of linear dependence between variables. For these needs, correlation analysis was performed, and the value of the Pearson coefficient was observed as a measure of correlation strength.

Table 2: Correlation results

\begin{tabular}{|c|c|c|c|c|c|}
\hline & Collectivism & Femininity & Activities & Interests & Opinions \\
\hline Collectivism & 1 & $0.687^{* \star}$ & $0.592^{\star \star}$ & $0.581 * *$ & $0.609 * \star$ \\
\hline Femininity & $0.687^{* *}$ & 1 & $0.632 * \star$ & $0.601 * \star$ & $0.611 * *$ \\
\hline Activities & $0.592^{* *}$ & $0.632^{* *}$ & 1 & $0.598 * *$ & $0.549 * *$ \\
\hline Interests & $0.581 * *$ & $0.601 * *$ & $0.598 * *$ & 1 & $0.709 * *$ \\
\hline Opinions & $0.609 * *$ & $0.611 * *$ & $0.549 * *$ & $0.709 * \star$ & 1 \\
\hline
\end{tabular}

** All coefficients are significant at 0.01 level

Source: authors

All obtained values of Pearson's correlation coefficient are statistically significant at the 0.01 level, i.e. with $99 \%$ probability, which confirms the presence of a linear dependence between variables (Table 2). The highest degree of correlation exists between interests and opinions while the weakest degree exists between activities and opinions.

In order to test research hypotheses, it is first necessary to determine whether the observed features of the Serbian cultural framework are confirmed. This can be determined based on the values of arithmetic means for national culture dimensions. By observing a seven-point Likert scale, values from 1 to 4 indicate a tendency towards individualism and masculinity, while values from 4.1 to 7 reflect a dominance of collectivism and femininity. For both dimensions the value of arithmetic mean is higher than 4 , so it can be confirmed that the Serbian national culture is collectivistic with the dominance of femininity (Table 3$)$. The obtained result is in line with the previous results (Vasilic \& Brkovic, 2017; Sapic \& Golo, 2017; Hofstede Insights, 2020). Also, results indicate the presence of a stronger tendency to maintain close ties with reference groups rather than to modesty and support to others.

Table 3: Mean values for national culture dimensions

\begin{tabular}{|c|c|}
\hline Dimension & Mean \\
\hline Collectivism & 5.62 \\
\hline Femininity & 5.24 \\
\hline
\end{tabular}

Source: authors

The obtained results enable testing of research hypotheses using structural equation modelling, where it is first important to test the reliability of research models using a confirmatory factor analysis.

Table 4: Confirmatory factor analysis and SEM results for first model

\begin{tabular}{|c|c|c|c|c|c|c|}
\hline Index & $\begin{array}{c}\text { Reccomended } \\
\text { value }\end{array}$ & Obtained value & Relations & $\boldsymbol{\beta}$ & $\mathbf{p}$ & $\mathbf{R}^{2}$ \\
\hline chi- & $<5$ & $77.070 / 30=2.57$ & Collectivism- & 0.389 & $0.026^{*}$ & \\
square/df & $>0.8$ & 0.950 & activities & & & 0.626 \\
GFI & $>0.9$ & 0.958 & & & \\
CFI & $>0.9$ & 0.921 & Femininity- & 0.430 & $0.021^{*}$ & \\
TLI & $>0.9$ & 0.957 & activities & & \\
IFI & $<0.08$ & 0.079 & RMSEA & & &
\end{tabular}

*Value is significant at 0.1 level Source: authors

All confirmatory factor analysis indexes are within recommended limits (Hair, Black, Babin \& Anderson, 2014; Malaquias \& Hwang, 2016) (Table 4). Also, it is noticed that both independent variables have a statistically significant influence on consumer activities since $p$ value for $\beta$ coefficient is lower than 0.1 for both variables. A stronger influence on consumer activities is found in femininity compared to collectivism due to a higher value of $\beta$ coefficient. The percentage of dependent variable variability described by the first model comprises $62.6 \%$. The obtained results confirm research sub-hypotheses $\mathrm{H} 1 \mathrm{a}$ and $\mathrm{H} 2 \mathrm{a}$. 
It is further necessary to examine influence of national culture dimensions on interests as second AIO component.

Table 5: Confirmatory factor analysis and SEM results for second model

\begin{tabular}{|c|c|c|c|c|c|c|}
\hline Index & $\begin{array}{c}\text { Reccomended } \\
\text { value }\end{array}$ & Obtained value & Relations & $\boldsymbol{\beta}$ & $\mathbf{P}$ & $\mathbf{R}^{\mathbf{2}}$ \\
\hline chi- & $<5$ & $52.671 / 26=2.02$ & Collectivism- & 0.917 & 0.193 & \\
square/df & $>0.8$ & 0.965 & interests & & & 0.631 \\
GFI & $>0.9$ & 0.977 & & & \\
CFI & $>0.9$ & 0.951 & Femininity- & -0.129 & 0.854 \\
TLI & $>0.9$ & 0.977 & interests & & \\
IFI & $<0.08$ & 0.064 & RMSEA & & &
\end{tabular}

without *: value is insignificant

Source: authors

The obtained values of indices indicate the suitability of the model for further analysis (Table 5). Independent variables do not show a statistically significant influence on consumer interests. The regression model covers $63.1 \%$ of the dependent variable variability. Based on presented results, it can be concluded that research sub-hypotheses $\mathrm{H} 1 \mathrm{~b}$ and $\mathrm{H} 2 \mathrm{~b}$ have not been proven.

The last analysis was conducted in order to test the influence of independent variables on opinions as the third component of $\mathrm{AlO}$ technique.

Table 6: Confirmatory factor analysis and SEM results for third model

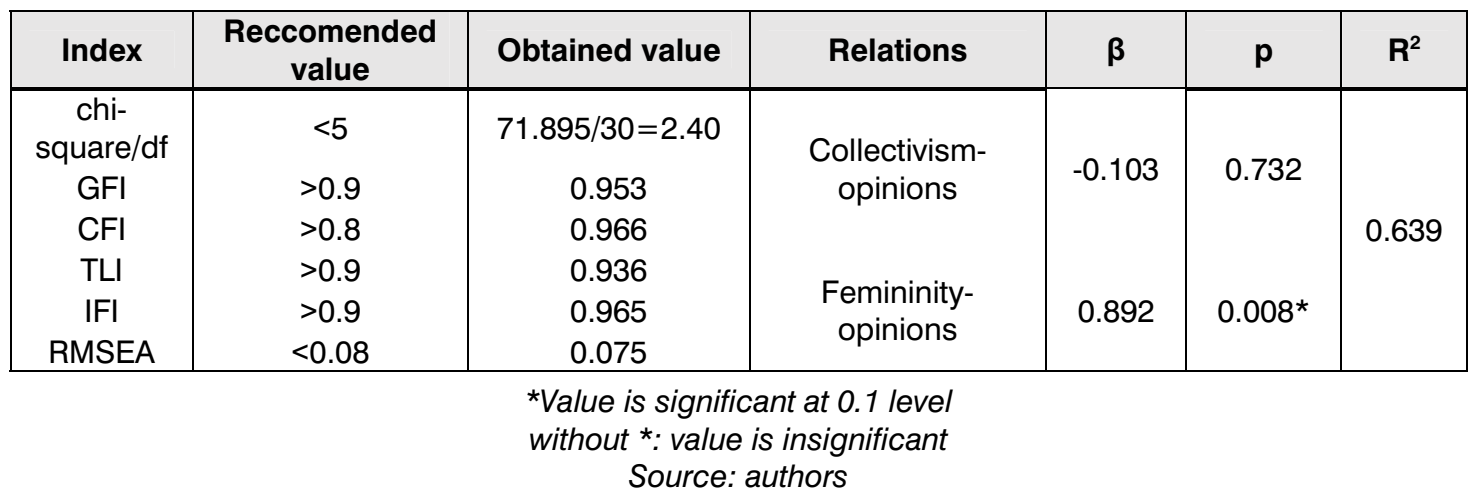

The results in Table 6 show that the third research model is suitable for further statistical analysis. $63.9 \%$ of the dependent variable variability is covered by the regression model. Results indicate the existence of statistically significant femininity effects and absence of collectivism influence on consumer opinions. Accordingly, it can be concluded that the research sub-hypothesis $\mathrm{H} 1 \mathrm{c}$ has not been proven, while the subhypothesis $\mathrm{H} 2 \mathrm{c}$ has been proven.

If we summarize the previously obtained results, we can conclude that the hypothesis $\mathrm{H} 1$ regarding the effects of collectivism on lifestyle has not been proven, while the hypothesis $\mathrm{H} 2$ related to influence of femininity on consumer lifestyle has been partially proven.

\section{Conclusion}

The aim of the paper was to examine the influence of femininity and collectivism on activities, interests and opinions of consumers. The empirical study has first confirmed the presence of collectivism and femininity in the Serbian national culture, which corresponds to the results of the research conducted by Hofstede (Hofstede 1980; Hofstede Insights, 2020), and then indicates the existence of a statistically significant effect of observed cultural dimensions on AIO components, i.e. consumer lifestyle. Femininity most strongly determines consumer opinions regarding personal perception, financial future and influence of lifestyle on shopping decisions, and then activities such as regular shopping, discount shopping and watching television. When it comes to consumer interest in new and different things, nice clothes and touring the world, femininity has not proven to be a significant predictor of these. Collectivism has effects only on consumer activities while it 
does not influence formation of their opinions and interests. This indicates that the lifestyle of Serbian consumers is shaped by their tendencies towards modesty, help and support to others much more than by a tendency to have close relationships with groups from the environment. The results related to the presence of significant collectivism effects on consumer lifestyle are not consistent with the results of studies by Sun et al. (2004) or Nagy and Konyha (2018), but are similar to the results of research conducted by Tao (2006) which also pointed out the absence of that effect. In view of the presence of femininity effects on consumer lifestyle, they are confirmed as in the research by the author Tao (2006), but results differ when observing studies by authors such as Tan et al. (2013) or Nagy and Konyha (2018) who have not determined this influence.

Given the fact that research in this domain is rare and that it is almost non-existent in domestic literature, the paper enables analysis of national culture effects on consumer lifestyle development. According to authors' knowledge, the literature lacks studies that investigate the influence of Hofstedes' national culture dimensions on activities, interests and opinions as lifestyle components. The analysis of the relationship between these two determinants of consumer behaviour provides useful insights into their interdependence, which ultimately has a strong impact on overall consumer behaviour as evidenced by the Kotler and Keller (2017) model of consumer behaviour. The theoretical contribution of the paper is, according to the aforementioned, based on setting and empirically testing the proposed research model which can be used in future cross-cultural or consumer behaviour studies. Also, the paper provides useful practical knowledge regarding the influence of cultural dimensions on consumers with certain psychographic characteristics and their behaviour, as well as regarding the importance of knowing and respecting cultural differences when defining marketing strategies aimed to shape consumer lifestyles. Such knowledge is especially useful for companies operating in international market. By formulating and implementing marketing strategies based on the obtained knowledge regarding consumer cultural orientation, companies can provide a better access to the targeted market segments. Further, the conducted psychographics analysis creates additional possibilities for marketing strategies adaptation and provides focus on those psychographics segments that are valuable for company business. Finally, companies should use the effects of the observed cultural specifics on shaping consumer lifestyle as business opportunities. Despite contributions, work limitations are an insufficiently representative sample, observation of only two dimensions of national culture and neglect of national culture effects on lifestyle depending on demographic characteristics of consumers. In accordance with the above, it is recommended that the future research should primarily include a larger sample of respondents, apply a holistic approach indicated by Janicijevic (2003) which will include examining a common effect of national culture dimensions on consumer lifestyle and possibly focus on moderator effects analsysis of consumer demographic characteristics when examining the influence of national culture on lifestyle. It is desirable to perform a psychographic segmentation of consumers based on activities, interests and opinions as important psychographic criteria. Recommendations can be given to marketers related to the development of business strategies based on knowledge and adaptation to cultural specifics of business areas and their influence on consumer lifestyle. In this regard, when presenting an offer to target market in Serbia, marketers should adjust their marketing strategy to femininity due to the effects that the observed dimension has on consumer lifestyle. This can be achieved by promoting benefits of products and services not only for the consumer but also for his environment, which would help promotional strategy to achieve better effects on consumers in Serbia because they show a growing tendency to care and support others. Regarding collectivism as a dimension of culture that also determines lifestyle, recommendations may refer to highlighting benefits that a product or service offers for the whole family or showing their purchases together with family or friends to enhance effects of the observed dimension when it comes to consumer lifestyle components, especially their opinions and interests. This can be particularly interesting for service providers such as beauty salons, hotels, restaurants or cafes as they could promote consumption of their services by family or friends as a reflection of collective spirit.

\section{REFERENCES}

[1] Albors-Garrigos, J., Frass, A., Peiro Signes, A. (2017). Impact of national cultures on automotive sector after sales services perception. Management Journal of Sustainable Business and Management Solutions in Emerging Economies, 22(2), 13-27. DOI: https://doi.org/10.7595/management.fon.2017.0014

[2] Al-Dmour, R., Hammdan, F., Al-Dmour, H., Alrowwad, A., Khwaldeh, S. (2017). The effect of lifestyle on online purchasing decision for electronic services: the Jordanian flying e-tickets case. Asian Social Science, 13(11), 157-169. DOI: 10.5539/ass.v13n11p157

[3] Beugelsdijk, S., and Welzel, C. (2018). Dimensions and dynamics of national culture: Synthesizing Hofstede with Inglehart. Journal of Cross-Cultural Psychology, 49(10), 1469-1505. DOI: $10.1177 / 0022022118798505$

[4] Brocic, Lj. (1995). Stil zivota tradicionalnih i novih profesija: analiza rezultata jednog socioloskog istrazivanja. Glasnik etnografskog instituta SANU, 44, 138-142.

[5] Bruwer, J., Roediger, B., and Herbst, F. (2017). Domain-specific market segmentation: a wine-related lifestyle (WRL) approach. Asia pacific journal of marketing and logistics, 29(1), 4-26. DOI: 10.1108/APJML10-2015-0161

[6] Chouk, I., and Mani, Z. (2019). Factors for and against resistance to smart services: role of consumer lifestyle and ecosystem related variables. Journal of Services Marketing, 33(4), 449-462. DOI: 10.1108/JSM-01-2018-0046/full/html 
[7] Cleveland, M., Rojas-Mendez, J. I., Laroche, M., and Papadopoulos, N. (2016). Identity, culture, dispositions and behavior: A cross-national examination of globalization and culture change. Journal of Business Research, 69(3), 1090-1102. DOI: 10.1016/j.jbusres.2015.08.025

[8] Cossio-Silva, F. J., Revilla-Camacho, M. A., Vega-Vazquez, M., and Palacios-Florencio, B. (2016). Value cocreation and customer loyalty. Journal of Business Research, 69(5), 1621-1625. DOI: 10.1016/j.jbusres.2015.10.028

[9] de Mooij, M. (2017). Comparing dimensions of national culture for secondary analysis of consumer behavior data of different countries. International Marketing Review, 34(3), 444-456. DOI: 10.1108/IMR02-2016-0047

[10] Donnelly, T. T., Al Suwaidi, J., Al Bulushi, A., Al Enazi, N., Yassin, K., Rehman, M. A., Hassan, A. A., and Idris, Z. (2011). The influence of cultural and social factors on healthy lifestyle of Arabic women. Avicenna, 2011(1), 1-13. DOI: http://dx.doi.org/10.5339/

[11] Guseva, N. (2013). Cultural aspects of decision-making in online purchases. Trziste, 25(1), 7-20.

[12] Hair, Jr. J. F., Black, W. C, Babin, B. and Anderson E. Roph. (2014). Multivariate Data Analysis. Harlow, Essex: Pearson Education Limited.

[13] Hofstede, G. (1980). Motivation, leadership, and organization: do American theories apply abroad?. Organizational dynamics, 9(1), 42-63.

[14] Hofstede, G. (1994). The business of international business is culture. International business review, $3(1), 1-14$.

[15] Hofstede Insights. (2020). Country comparison-Serbia. Retreived from: https://www.hofstedeinsights.com/country-comparison/serbia/

[16] Iversen, N. M., Hem, L. E., and Mehmetoglu, M. (2016). Lifestyle segmentation of tourists seeking nature-based experiences: The role of cultural values and travel motives. Journal of Travel and Tourism Marketing, 33(sup1), 38-66. DOI: 10.1080/10548408.2014.998359

[17] Janicijevic, N. (2003). Uticaj nacionalne kulture na organizacionu strukturu preduzeca u Srbiji. Ekonomski anali, 44(156), 45-66. DOI: 10.2298/EKA0356045J

[18] Jensen, M. (2007). Defining lifestyle. Environmental sciences, 4(2), 63-73. DOI: $10.1080 / 15693430701472747$

[19] Kabir, T., and Sarker, C. B. (2015). Effect of cultural dimensions on customers' susceptibility to interpersonal influence in the context of Bangladesh. Prime University Journal, 9(1), 77-108.

[20] Katz, L. D. (2014). Lifestyle is the medicine, culture is the spoon: the covariance of proposition and preposition. American Journal of Lifestyle Medicine, 8(5), 301-305. DOI: 10.1177/1559827614527720

[21] Kotler, P., and Keller, L. K. (2017). Marketing Management. New Jersey: Pearson Prentice Hall.

[22] Kovac-Znidersic, R., and Maric, D. (2007). Drustvene determinante ponasanja potrosaca. Subotica: Ekonomski fakultet

[23] Kucukusta, D., and Denizci Guillet, B. (2016). Lifestyle segmentation of spa users: A study of inbound travelers to Hong Kong. Asia Pacific Journal of Tourism Research, 21(3), 239-258. DOI: 10.1080/10941665.2015.1025087

[24] Langat, D., and Oudor, P. (2015). The effects of Hofstede's dimensions of culture on consumer purchase decisions amongst the Kipsigis community: a case study of Bomet county. Strategic Journal of Business and Change Management, 2(14), 249-267.

[25] Lazer, W. (1963). Life style concepts and marketing. In S. A. Greyser (ed.), Toward scientific marketing (pp. 130-139). Chicago: American Marketing Association.

[26] Lawson, R. and Todd, S. (2002). Consumer lifestyles: a social stratification perspective. Marketing theory, 2(3), 295-307.

[27] Lee, H. S., and Sparks, B. (2007). Cultural influences on travel lifestyle: a comparison of Korean Australians and Koreans in Korea. Tourism Management, 28(2), 505-518.

[28] Malaquias, F. R., and Hwang, Y. (2016). An empirical study on trust in mobile banking: a developing country perspective. Computers in human behavior, 54, 453-461.

[29] Mangruwa, D. R., Zaki, S., Mahdzir, M. A., and Khalid, W. (2015). A review of cross-cultural analysis on energy behaviour consumption in residential building between Malaysia and Japan. Energy, 1990, 1-6.

[30] Mansson, D. H., and Sigurdardottir, A. G. (2017). Trait affection given and received: A test of Hofstede's theoretical framework. Journal of Intercultural Communication Research, 46(2), 161-172. DOI: $10.1080 / 17475759.2017 .1292944$

[31] Maricic, B. (2011). Ponasanje potrosaca. Beograd: Centar za izdavacku delatnost Ekonomskog fakulteta

[32] Mojic, D., Jovancevic, J., and Jovancevic, S. (2018). Culture and public administration reforms in postsocialist transformation: the case of Serbia. Sociologija, 60(3), 653-669. DOI: https://doi.org/10.2298/SOC1803653M

[33] Nagy, S., and Konyha, C. (2018). The effects of Hofstede's cultural dimensions on pro-environmental behaviour: how culture influences environmentally conscious behaviour. Club of Economics in Miskolc TMP, 14(1), 27-36. 
[34] Nguyen, T.N., Lobo, A., and Greenland, S. (2017). The influence of cultural values on green purchase behaviour. Marketing Intelligence and Planning, 35(3), pp. 377-396. DOI: 10.1108/MIP-08-2016-0131

[35] Rathod, M. R., and Soni, S. B. (2014). Life style of rural tribal consumers of Panchmahal district of Gujarat state. Journal of Management Research, 6(2), 93-98.

[36] Reid, M., Li, E., Bruwer, J., and Grunert, K. (2001). Food-related lifestyles in a cross-cultural context: comparing Australia with Singapore, Britain, France and Denmark. Journal of Food Products Marketing, 7(4), 57-75.

[37] Sharma, P. (2010). Measuring personal cultural orientations: scale development and validation. Journal of the Academy of Marketing Science, 38(6), 787-806. DOI: 10.1007/s11747-009-0184-7

[38] Sethna, Z., and Blythe, J. (2016). Consumer behaviour. UK: Sage Publications Ltd.

[39] Solomon, M., Bamossy, G., Askegaard, S., and Hoog, M. K. (2016). Consumer behaviour: a European perspective. UK: Pearson Education Limited.

[40] Sun, T., Horn, M., and Merritt, D. (2004). Values and lifestyles of individualists and collectivists: a study on Chinese, Japanese, British and US consumers. Journal of consumer marketing, 21 (5), 318-331. DOI: $10.1108 / 07363760410549140$

[41] Sapic, S. (2015). Medjunarodne marketing aktivnosti-kulturalna dimenzija. Kragujevac: Ekonomski fakultet.

[42] Sapic, S., and Golo, J. (2017). Uticaj dimenzija kulture na stavove i namere potrosaca prema stranim i domacim proizvodima. Marketing, 48(4), 235-242.

[43] Sapic, S., and Filipovic, J. (2019). Medjunarodni marketing. Kragujevac: Ekonomski fakultet

[44] Tao, S. P. (2006). A cross-cultural comparison of life style between Taiwanese and US consumers. Intercultural Communication Studies, 15(1), 43-57.

[45] Tan, Y., Shaw, P., Cheng, H., and Kim, K. K. (2013). The construction of masculinity: a cross-cultural analysis of men's lifestyle magazine advertisements. Sex Roles, 69(5-6), 237-249. DOI: 10.1007/s11199013-0300-5

[46] Vasilic, N. G., and Brkovic, P. (2017). Nacionalna kultura kao determinanta stavova o stilovima liderstva. Skola biznisa, 2/2017, 38-55. DOI: 10.5937/skolbiz2-15581

[47] Viljoen, A. T., van der Spuy, E., and du Rand, G. E. (2018). Food consumption, lifestyle patterns, and body mass index of a group of white South African students. International Journal of Consumer Studies, 42(5), 533-546. DOI: 10.1111/ijcs.12465

[48] Wells, D. W., and Tigert, J. D. (1971). Activities, interests and opinions. Journal of advertising research, 11(4), 27-35.

[49] Wild, J. J., and Wild, K. L. (2016). International Business: The Challenges of Globalization (8 ${ }^{\text {th }}$ edition). UK: Pearson Education Limited.

[50] Yau, O. (1994). Consumer Behavior in China: Customer Satisfaction and Cultural Values. London: Routledge.

[51] Yoo, B., Donthu, N. and Lenartowicz, T. (2011). Measuring Hofstede's five dimensions of cultural values at the individual level: development and validation of CVSCALE. Journal of international consumer marketing, 23(3-4), 193-210. DOI: 10.1080/08961530.2011.578059

[52] Zhang, H., Lu, L., and Sun, F. (2021). Changing role of lifestyle in tourism entrepreneurship: Case study of Naked Retreats Enterprise. Tourism Management, 84 (2021), 104259. DOI: 10.1016/j.tourman.2020.104259

[53] Zolt, L., and Kokovic, D. (2017). Sociologija kulture: sa elementima kulturne antropologije. Novi Sad: Mediterran Publishing.

Received: 2020-10-28

Revision requested: 2021-04-12

Revised: 2021-05-26 (2 revisions)

Accepted: 2021-05-27

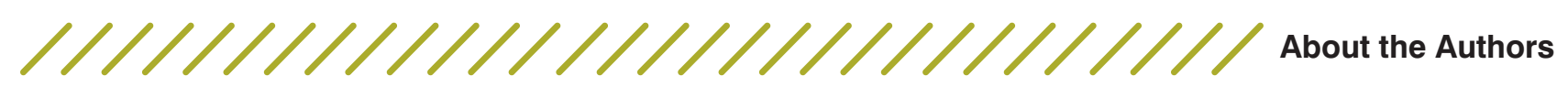

$$
\begin{array}{r}
\text { Srđan Šapić } \\
\text { University of Kragujevac, Faculty of Economics, Serbia } \\
\text { ssapic@kg.ac.rs }
\end{array}
$$

Srđan Šapić was born in 1971 in Kragujevac. He works as a full professor at the Faculty of Economics, University of Kragujevac. His area of expertise is international marketing and international business, with the focus on cultural environment, international marketing communications and forms of enterprises internationalization.

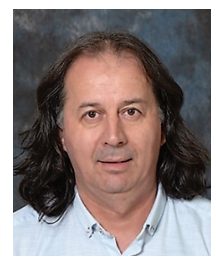




\section{Jovana Lazarević}

University of Kragujevac, Faculty of Economics, Serbia

jsavic@kg.ac.rs

Jovana Savic was born in Kragujevac, in 1992. From July 2018 she has been engaged at the Faculty of Economics, University of Kragujevac, as a Junior Researcher, and currently as a Research Associate. Jovana is interested in consumer behaviour and cross-cultural marketing.

Veljko Marinković

University of Kragujevac, Faculty of Economics, Serbia vmarinkovic@kg.ac.rs

Veljko Marinković was born in 1978 in Kragujevac. In 2019 he was appointed full professor at the Faculty of Economics, University of Kragujevac. His scientific interest area covers services quality, consumer satisfaction and loyalty measurement, mobile

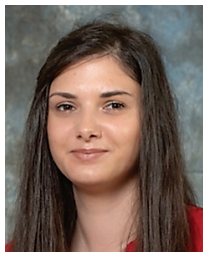
marketing, tourism marketing, consumer ethnocentrism. 